\title{
Spindle Pole Body
}

National Cancer Institute

\section{Source}

National Cancer Institute. Spindle Pole Body. NCI Thesaurus. Code C13365.

The spindle pole body (SPB) is the microtubule organizing center (MTOC) in the yeast Saccharomyces that plays a pivotal role in such diverse processes as mitosis, budding, and mating. (from Cell. 1997;89:1077-86) 